Article

\title{
Leadership, Identity and Performance: The Nature and Effect of 'Prototypicality' in Indonesia
}

\author{
David Hudson ${ }^{1, *}$, Claire Mcloughlin ${ }^{1}$, Anna Margret ${ }^{2}$ and Yolanda Pandjaitan ${ }^{2}$ \\ ${ }^{1}$ International Development Department, School of Government, University of Birmingham, Birmingham, B15 2TT, UK; \\ E-Mails: d.e.hudson@bham.ac.uk (D.H.), c.mcloughlin@bham.ac.uk (C.M.) \\ ${ }^{2}$ Cakra Wikara Indonesia, Department of Political Science, Faculty of Social and Political Science, University of Indonesia, \\ 16424 Java Barat, Indonesia; E-Mails: annamargret@cakrawikara.id (A.M.), yolanda.panjaitan@cakrawikara.id (Y.P.) \\ * Corresponding author
}

Submitted: 7 August 2020 | Accepted: 28 September 2020 | Published: 25 November 2020

\begin{abstract}
What makes a leader worthy of support? The article uses novel survey and experimental data from Indonesia to test the proposition that identity trumps performance for citizens perceptions of their political leaders. The results confirm theories of 'prototypicality'-leaders that best reflect and represent the identity of the group tend to be more trusted and have a licence to fail. We argue and show that the dimensions of identity that matter most varies and is context specific. In the Indonesian context religious identity is most important. But the data also suggest that this varies across space, time, and follower identity: We show that gender matters, as women are less easily persuaded by prototypicality. We conclude by reflecting on the implications for leaders, politics and support for leadership development.
\end{abstract}

\section{Keywords}

Indonesia; leadership; prototypicality; social identity theory; women in politics

\section{Issue}

This article is part of the issue "Leadership and Political Change in Asia-Pacific" edited by David Hudson (University of Birmingham, UK), Nicolas Lemay-Hébert (Australian National University, Australia), Claire Mcloughlin (University of Birmingham, UK) and Chris Roche (La Trobe University, Australia).

(C) 2020 by the authors; licensee Cogitatio (Lisbon, Portugal). This article is licensed under a Creative Commons Attribution 4.0 International License (CC BY).

\section{Introduction}

\subsection{Leadership Choices in Global Perspective}

What makes a leader worthy of support? Across a variety of different contexts, people evaluate leaders based on a range of factors; from their leadership style, to the position they inherited or obtained through talent and ability achieved (Corbett, 2019), to certain characteristics they display, such as competence, strength or charisma (Aaldering \& Vliegenthart, 2016). Why people choose leaders matters because it sets criteria against which citizens judge them as successful or not. It can influence whether people confer or withdraw support and, in turn, how far those leaders are responsive to people's interests. From a development perspective, understanding how people evaluate leaders is therefore key to understanding when and how change happens.

Leadership is not an individual 'heroic' act (Andrews, 2016). Rather, it is "a process of social influence in which one person is able to enlist the aid and support of others in the accomplishment of a common task" (Chemers, 2002 , p. 1). All leaders need followers and leadership works through a political process of interaction between followers' evaluations and leaders' actions (Hudson \& Mcloughlin, 2019). In practice, we often see puzzling relationships between what might be perceived to be in followers' interests, and how leaders act: Charismatic leaders can be extremely popular, but ultimately ineffective at driving change, while transformational leaders may be extremely effective at improving lives, but highly unpopular. By uncovering what's going on beneath the surface of 
the leader-follower relationship, we can therefore start to unpick when and how it might be enabling or disabling progressive, developmental reform. For example, if we want to understand why leaders sometimes retain their legitimacy when they fail to deliver on their promises, or when leaders who do deliver may fail to hold onto power, we can examine how followers are evaluating them.

In this article we test how people evaluate leaders, with an emphasis on the power of identity in shaping this evaluation. The social identity theory of leadership predicts that people are more likely to support leader 'prototypes'-leaders who reflect and represent the identity of the group that they themselves most closely identify with (Hogg \& Knippenberg, 2003). In turn, being a prototypical leader can have important effects on how people evaluate these leaders, as compared to non-prototypical leaders who may be seen as relative outsiders. Using a survey experiment in Indonesia we test the core propositions of this theory. Our contribution to this nascent literature is novel in two ways. First, much of the existing literature has been confined to the social psychology, management or organisational sciences. We expand this to test whether and how this theory holds in the public, political domain. Second, we extend this literature from its focus on developed countries in the West, to an Asian setting.

We argue-and our findings confirm - that identity (and prototypicality in particular) is a key (possibly the key) way that citizens perceive, assess and therefore support or not their leaders. The implications of this are many, profound, and questionably progressive-though potentially so. We find that identity typically trumps performance when it comes to citizen assessments of trust, capability and protection. The results of our survey in Indonesia add much detail to the more general thesis. Plus, we argue, that the specifics of the Indonesian case underline the point that the particular dimensions of identity that matter in each context is precisely that: context specific. Identity matters, but which dimensions matter vary. In the Indonesian context we find that religious identity trumps ethnicity. We also use a variety of different survey questions and techniques to show that while many people say that gender is not a key category, respondents' revealed preferences show that it typically is. We also confirm that prototypicality primarily works through people's assessment of trustworthiness. Finally, and importantly, the effects of prototypicality are not uniform -in our data women are less easily persuaded by prototypicality and the provincial context matters.

The article proceeds as follows. First, we set out the core propositions of the social identity theory of leadership, reviewing findings from past research. Second, we set the scene for our study by describing why these questions are pertinent in the case of Indonesia, and outline the methodology we used to explore them in this context. Third, we present the findings for each of our research questions in turn. Finally, we conclude with implications for Indonesia and, more widely, for understanding the role of identity in leadership for development.

\subsection{The Social Identity Theory of Leadership}

A popular theory from the leadership and social psychology literature says that other things held constant, people evaluate leaders based on their identity. This social identity theory of leadership predicts that people will look for leaders who reflect the identity and characteristics of the group they feel most closely associated with (Hogg \& Knippenberg, 2003). The underlying premise is that individuals perceive leaders through the lens of their social group because groups "define who we are, and influence what we think, feel, and do, and how others perceive and treat us" (Hogg, van Knippenberg, \& Rast, 2012). Indeed, people look to leaders to define their group identity, and whether this is more or less shaped by attributes such as ethnicity, religion, gender, or by certain values or traditions. Leaders who reflect and embody this identity can be thought of as 'prototypical' leaders. Such a leader would be likely be considered a typical group member-'one of us' - and as such, someone who best understands and is willing to defend the interests of the group.

Looking or behaving like a prototypical leader matters because it can have real effects on how followers evaluate them. In the literature, there are two particularly striking propositions about the effects of prototypicality on follower perceptions. First, people are more likely to endorse, trust and support prototypical leaders. In other words, they are more likely to judge 'ingroup' members more favourably than 'outgroup' members with the same characteristics (Marques \& Paez, 1994). Empirical tests carried out across a broad suite of contexts seem to confirm a strong preference towards prototypical group leaders (Reicher, Haslam, \& Platow, 2018). These and other studies explain this preference because people tend to think that prototypical members are more likely to be invested in the group, inherently trustworthy, and better able to promote group interests.

Second, because of their identity, prototypical leaders can behave differently to non-prototypical leaders without the same consequences as non-prototypes. Some studies have found that because prototypical members are perceived to be more legitimate and trustworthy, they may not always need to act in followers' interests, be effective, or act fairly, to retain support. Sometimes they can retain this trust even when they are ineffective at delivering benefits for the group. In other words, while non-prototypical leaders may have to perform well to gain trust, prototypical leaders can sometimes are granted a 'license to fail' simply because of their identity (Giessner, van Knippenberg, \& Sleebos, 2009; Hogg \& Knippenberg, 2003). Some lab experiments even suggest that identity can override perceptions of fairness; people may support prototypical leaders whether they are considered fair or not (Ullrich \& 
Christ, 2009). Because people trust prototypical leaders, it may also be the case that such leaders have more latitude to diverge from group norms, or seek to change them (Abrams, de Moura, Marques, \& Hutchison, 2008). In other words, prototypical leaders may also have more leeway to be transformational-to push the boundaries of norms, and even go against the interests of the group, while retaining their legitimacy. So, while the idea of identity trumping merit may be a cause of concern, it is also worth flagging that, conditional on prototypical leaders' motivations, values, and priorities, this could be good news for progressive, developmental change. Developmental leadership will often involve bending or breaking social norms and existing institutions to bring about change (Hudson, Mcloughlin, Marquette, \& Roche, 2018). Prototypicality may help do this-for good or for ill.

A small but significant body of empirical work has investigated the conditions under which these prototypicality effects hold, and how strongly. One key question, recently addressed by Baretto and Hogg (2017), is how much variance in leadership evaluation can be attributed to protoypicality, versus other important dimensions of assessment, such as leadership style or personality. Overall, they found a strong effect of prototypicality on trust, and a moderate effect on evaluations of effectiveness. Likewise, elsewhere, several factors have been found to moderate the prototypicality effect. These include how strongly members associate with their group (Giessner et al., 2009), and the leader's gender (Hogg et al., 2006). The prototypicality effect has been found to weaken when individuals face uncertainty about their own self-identity (Rast, Gaffney, Hogg, \& Crisp, 2012).

While this new theory and emerging body of research is producing robust and increasingly nuanced findings, it has also been limited in scope. The majority of analysis to date has been located in the organisational and management sciences, or social psychology. All of the 35 selected studies that Baretto and Hogg (2017) examined in their metanalysis addressed prototypicality in organisational settings, or via lab experiments. This study seeks to address some of these gaps and extend the utility of the social identity theory in other spheres of public life. It offers a novel test of the social identity theory, by examining the relationship between prototypicality and support for political leadership in Indonesia.

\section{Examining Prototypical Leadership in Indonesia}

\subsection{The Indonesian Case}

The research set out to test some of the key propositions that arise from the social identity theory of leadership in the Indonesian context. Following the standard in this field (van Knippenberg, 2011), our approach first identifies what prototypical leadership looks like across our research site, and then examines the effects that being a prototype, or non-prototype, has on leader evaluations. Several aspects of our approach are relatively novel within this nascent literature. First, our approach is based on respondents' preferences for the social identity characteristics of leaders, rather than on any preconceived assumptions or hypothetical constructs. In this way, we can develop a perceptions-based, empirical picture of what a prototypical leader actually looks like and crucially, demonstrate how those prototypes vary across individuals with different identity characteristics, as well as across spaces. Second, while the majority of previous studies have measured the effects of leader prototypicality on leadership evaluations in terms of either trustworthiness or effectiveness, we compare the effects of prototypicality versus non-prototypicality on both of these dimensions of assessment. Finally, we experiment with the effect of 'failure' on evaluations of prototypical versus non prototypical leaders, again showing how this effect varies across the demographics of the respondents.

Indonesia is a pertinent case for two reasons. First, it was an authoritarian regime for over 30 years, only experiencing direct elections of their leaders since mid-2000. Indonesia's "transition to electoral democracy" (Bunte \& Ufen, 2009, p. 12 can be traced to 1999, when the country had its first democratic election following the resignation of Suharto from his three-decades Presidency that also marked the end of the New Order Regime. During that period, Indonesians had regular five-year general elections, but saw no transfer of power, while all local leaders were appointed by the national government. Against such centralized power structures and strong military role, support for the political leadership was taken for granted. The first direct elections happened in 2004 for the President and in 2005 for local government leaders. As such, Indonesians have recently learned firsthand the importance of having the knowledge to assess the effectiveness and trustworthiness of a leader that they could now directly choose. Second, direct local elections in Indonesia have seen rampant money politics (Aspinall \& Mas'udi, 2017) and "identity-based mobilizations" (Davidson, 2018) impeding vertical accountability between constituents and their leaders.

The link between identity and leadership is particularly salient for Indonesia. As the world's largest Muslimmajority country, with a heterogeneous ethnic and sociocultural background, identity politics can be readily mobilized for support or resistance in elections. A number of scholars have highlighted how the rise of religious intolerance and identity politics, coupled with hardliner populists, may pose a potential stumbling block to the growth of democracy in Indonesia (Bourchier, 2019; Fealy, 2013; Hefner, 2019; Menchik, 2019; Mietzner, 2014; Power, 2018). In the context of a country flagged as potentially facing democratic stagnation (Mietzner, 2020), understanding people's perception of trustworthy and effective leadership may provide important insights into how to move forward. 


\subsection{Data and Method}

To study people's perceptions of what makes a leader effective and trustworthy in Indonesia, we focused on the lowest elected level of political leadership. In Indonesia, this is the heads of districts, the Bupatis or Walikota. We surveyed 5 provinces: Jakarta, North Sumatra, West Java, East Java, and South Sulawesi. These were chosen because they are among the most densely populated areas, and also because each has particular political dynamics which allow us to test whether the theory holds across different contexts. In all five provinces, there are various ethnic groups with diverse dialects and local languages. In North Sumatra, the practice of clientelism in politics is strong, as reported by survey and election reports (Bawaslu, 2019). North Sumatra is also known to be home to a significant portion of Indonesia's Christian population. As the capital city, Jakarta is an important political, cultural and economic hub. It also represents a 'melting pot' of various ethnic groups migrating to make a living in the city. West Java is a business and political centre, and also the native homeland of Sundanese people, who form the largest ethnic group. This province is known to be politically conservative, with a predominant religious (Islam) influence. East Java is the second most populated province after West Java. While ethnic Javanese make up the majority of the population, the province also has a significant portion of minority groups. This province is the home of Nadhatul Ulama, the biggest Muslim mass-organization in Indonesia. South Sulawesi is widely known as having a political system predominantly influenced by dynasty politics, strong traditional communities as well as religion.

Purposive non-probability sampling was used to select the provinces, as per above, but once we had identified our survey locations we used a stratified sampling frame that targeted a representative sample by gender and age within the five provinces of interest. Weights were used to correct any remaining differences between the sample and provincial population, the distribution across the provinces is shown in Table 1 . The respondents were taken from an online panel. The final sample was 2,003 respondents. The fieldwork was conducted by Deltapoll in partnership with Viga.

We collected a range of demographic data on survey respondents, including their age, gender, province, profession, level of education, religion, ethnicity, personal monthly income. We also collected a range of attitudinal data, including their self-reported personality, religiosity or strength of faith, position with respect to traditions.

The survey contained three parts, and the methodology was tailored to address three research questions, set out below. The first is the following:

RQ1: What does a prototypical leader look like, and does this vary by individuals, groups and across different parts of Indonesia?

In order to understand what a prototypical leader looks like in Indonesia, respondents were asked a number of questions about their group identity and the characteristics they think leaders should have. Respondents were first asked to indicate the three most important characteristics that matter to their group identity. The options were: age, gender, ethnicity, religion, education, province and nationality.

Respondents were then asked to construct two different leader profiles. Based on social identity theory, we identified seven key characteristics for them to select from: gender, age, faith, ethnicity, leadership style, religiosity, and attitude towards existing traditions. Each of these characteristics could be selected on a number of levels, which are shown in Table 2. Respondents were told that the first leader profile should represent the kind of leader that they personally would prefer to see in power. The second leader profile should look like the kind of leader they believe is most likely to represent the wider interests of the group that they identify with. They were told that the two profiles may look the same or be different from one another.

The second research question is the following:

RQ2: What effect does prototypicality have on perceptions of trustworthiness, effectiveness, and representation of interests?

To test the difference a prototypical leader makes on people's perceptions of trustworthiness, effectiveness, and representation of their interest, our 2,003 respondents were then randomly assigned to two groups. The first group were shown a leader profile that matched their prototypical leader (Group P)-i.e., the kind of leader they had identified as most likely to represent the wider interests of the group that they identify with. The sec-

Table 1. Survey sample by province.

\begin{tabular}{|c|c|c|c|c|c|c|c|c|c|c|}
\hline & \multicolumn{2}{|c|}{ East Java } & \multicolumn{2}{|c|}{ Jakarta Special } & \multicolumn{2}{|c|}{ North Sumatra } & \multicolumn{2}{|c|}{ South Sulawesi } & \multicolumn{2}{|c|}{ West Java } \\
\hline Respondents & \multicolumn{2}{|c|}{483} & \multicolumn{2}{|c|}{624} & \multicolumn{2}{|c|}{246} & \multicolumn{2}{|c|}{128} & \multicolumn{2}{|c|}{522} \\
\hline Age mean & \multicolumn{2}{|c|}{33.4} & \multicolumn{2}{|c|}{32.2} & \multicolumn{2}{|c|}{31.2} & \multicolumn{2}{|c|}{31.8} & \multicolumn{2}{|c|}{31.5} \\
\hline Age standard deviation & \multicolumn{2}{|c|}{15.0} & \multicolumn{2}{|c|}{13.9} & \multicolumn{2}{|c|}{16.3} & \multicolumn{2}{|c|}{16.4} & \multicolumn{2}{|c|}{13.0} \\
\hline Gender & Female & Male & Female & Male & Female & Male & Female & Male & Female & Male \\
\hline Percentage & $49.4 \%$ & $50.6 \%$ & $49.1 \%$ & $50.9 \%$ & $49.6 \%$ & $50.4 \%$ & $50.3 \%$ & $49.7 \%$ & $48.9 \%$ & $51.1 \%$ \\
\hline
\end{tabular}


Table 2. Leaders profile characteristics and levels.

\begin{tabular}{|c|c|c|c|c|c|c|c|}
\hline \multirow{4}{*}{$\begin{array}{l}\text { Gender } \\
\text { Age } \\
\text { Religious faith }\end{array}$} & \multicolumn{7}{|c|}{ Levels } \\
\hline & \multicolumn{3}{|c|}{ Female } & \multicolumn{2}{|r|}{ Male } & \multirow{2}{*}{\multicolumn{2}{|c|}{67 years old }} \\
\hline & 27 years old & 37 years old & \multirow{2}{*}{\multicolumn{2}{|c|}{$\begin{array}{l}47 \text { years old } \\
\text { olic Christian }\end{array}$}} & 57 years old & & \\
\hline & Muslim & ant Christian & & & Hindu & Buddhist & Confucian \\
\hline \multirow[t]{2}{*}{ Ethnicity } & Jawa & Sunda & Batak & & Madura & & Betawi \\
\hline & Bugis & Tionghoa & Bali & & Makassar & $\begin{array}{l}\text { An } \\
\text { East }\end{array}$ & $\begin{array}{l}\text { thnic group of } \\
\text { Nusa Tenggara }\end{array}$ \\
\hline Religiosity & $\begin{array}{c}\text { They do not regularly } \\
\text { attend a place } \\
\text { of worship }\end{array}$ & \multicolumn{2}{|c|}{$\begin{array}{l}\text { They observe major } \\
\text { festivals, but do not } \\
\text { regularly attend a place } \\
\text { of worship }\end{array}$} & \multicolumn{2}{|c|}{$\begin{array}{l}\text { They regularly attend } \\
\text { their place of worship }\end{array}$} & $\begin{array}{l}\text { They ha } \\
\text { faith ar } \\
\text { centr }\end{array}$ & $\begin{array}{l}\text { de a very strong } \\
\text { d make religion } \\
\text { al to their life } \\
\text { nd work }\end{array}$ \\
\hline Tradition & $\begin{array}{l}\text { They want to restore } \\
\text { traditions and return } \\
\text { things to how they were }\end{array}$ & \multicolumn{2}{|c|}{$\begin{array}{l}\text { They want to protect } \\
\text { existing traditions to keep } \\
\text { things how they are }\end{array}$} & \multicolumn{2}{|c|}{$\begin{array}{l}\text { They tend to overlook } \\
\text { existing traditions and } \\
\text { go their own way }\end{array}$} & $\begin{array}{r}\text { They } \\
\text { existin } \\
\text { repla } \\
\text { a }\end{array}$ & $\begin{array}{l}\text { ant to abolish } \\
\text { traditions and } \\
\text { ce them with } \\
\text { lew vision }\end{array}$ \\
\hline
\end{tabular}

ond group was shown a randomly created leader profile that was non-prototypical (Group NP). Both groups received a manifesto statement from either their prototypical leader or a non-prototypical leader. The manifesto statement was identical for the two groups, the only difference being the leader profile (see Figure 1 for an example).

Respondents were then asked to indicate the extent to which they: (1) could trust this leader, (2) thought they would be a capable leader, and (3) felt the leader would represent their interests. All responses were on a scale of 0 to 9 , where 0 indicates strongly disagree and 9 indicates strongly agree.

The third research question is the following:

RQ3: Are prototypical leaders more likely than nonprototypical leaders to be supported, even when they are ineffective?
Next, we wanted to find out whether people judge the performance of prototypical and non-prototypical leaders differently. The literature suggests that prototypical leaders can retain trust and legitimacy even if they fail or go against followers' interests, while non-prototypical leaders struggle to build trust or legitimacy even when they deliver developmental goods.

To test this, we added a second randomisation where the respondents kept their prototypical or nonprototypical leader profile but were given further information about whether the leader was successful or failed to achieve their manifesto goals (see Table 3 for the statements). Of the group that kept their prototypical leader profile, half of them were told that five years later the leader had been successful. The other half were told that their prototypical leader had failed. The same treatment was given to the group who had a non-prototypical

\begin{tabular}{|c|}
\hline Leader Profile \\
Male \\
\hline 37 years old \\
\hline Muslim \\
\hline Javanese \\
\hline They are able to get things done \\
\hline They regularly attend \\
their place of worship \\
\hline $\begin{array}{c}\text { They seek to protect existing traditions } \\
\text { to keep things how they are }\end{array}$ \\
\hline
\end{tabular}

"I am proud to be selected as your representative. My number one priority in office is to reform our community's schools and health clinics to make sure that they go to the people most in need and are the people who will benefit the most. Reform will not be easy and it will involve many costs. but I am determined to succeed."

Figure 1. Example leader profile and manifesto. 
Table 3. Success and failure treatments.

Success treatment $\quad 5$ years later, at the end of their term of office, this leader had successfully delivered on their promise to reform the schools and health clinics in the Kabupaten. The reforms were hard won, but resulted in improved literacy levels and access to essential medicines.

Failure treatment 5 years later, at the end of their term of office, this leader had failed to deliver on their promise to reform the schools and health clinics in the Kabupaten. The reforms were unsuccessful: the investment and hard work was wasted and there was no improvement in literacy levels or access to essential medicines.

leader profile. Half of them were told that five years later the non-prototypical leader had been successful, and the other half were told that the non-prototypical leader had failed. In effect, the randomisation meant that the sample was evenly split across four treatment groups, as per the $2 \times 2$ shown in Table 4 .

\section{Findings and Discussion}

\subsection{Results}

\subsubsection{Research Question 1}

Our first question went as follows:

Many people belong to a larger group of people because of a shared culture, history, background, interests or identity. Thinking about the group(s) of people you identify most strongly with, please indicate the first, second and third most important characteristics that matter to your group identity.

As shown in Figure 2, the most common response was nationality, where $67 \%$ of respondents selected 'being a fellow Indonesian' as their first, second, or third ranked most important characteristic. This is followed by having a shared religion (61\% of respondents ranked this option), education (47\%), age (45\%-though note $19.5 \%$ ranked it first), ethnicity (27\%), region (27\%), and finally gender (26\%).

We also then modelled respondents' choices to see whether different sub-groups of our sample tended to favour different characteristics. We collapsed the three ranked choices into a single outcome variable of 'chosen' (1) or 'not chosen' (0) and ran a series of binary logistic regressions on each group identity characteristic. We then calculated the average marginal effects, mean- ing we can report here the average change in probability of a characteristic being chosen by different respondent characteristics compared to a baseline category, averaging over all other observations in the sample. We looked to see whether the respondent's gender, age, education, ethnicity, province, religion and religiosity predicted the likelihood of selecting the seven group identity characteristics shown in Figure 2. We do not report the full results here, but identify the key substantively and statistically significant predictors.

Being from the same religion was the second most frequently mentioned category for respondents. Those who identify as being ethnically Betawi or Minangkabau were more likely to select religion, as are respondents from West Java. But identifying as Muslim or Hindu are the most important predictors of selecting religion (increasing the probability of selecting by $47 \%$ and $39 \%$, respectively). Respondents' religiosity matters too. Those who regularly attend their place of worship were $16 \%$ more likely to select and those who make their faith central to their life were $18 \%$ more, compared with those who only attend for major festivals. Taken together these results suggest a stronger prioritisation of religion as a key identity category for these two faiths (compared with Christians, Buddhists, and those of other faiths) and all individuals with stronger religiosity (regardless of faith).

Finally, being the same gender mattered more for male respondents; they were $14 \%$ more likely than female respondents to say that being from the same gender matters to their group identity. This tells us that men identify with fellow men more than fellow women identify with fellow women, as a category of group identity.

In order to understand the importance of identity further, we then asked our respondents to 'build' their own personal ideal leaders and what they believed would be a prototypical leader for their identity group. This time

Table 4. The four treatment groups based on prototypicality and non-prototypicality and policy success and failure.

\begin{tabular}{lcc}
\hline & $\begin{array}{c}\text { Prototypical } \\
\text { leader profile }\end{array}$ & $\begin{array}{c}\text { Non-prototypical } \\
\text { leader profile }\end{array}$ \\
\hline Success treatment & Group PS & $\begin{array}{c}\text { Group NPS } \\
(25.3 \% \text { of sample })\end{array}$ \\
Failure treatment & Group PF & Gample) \\
& $(24.1 \%$ of sample $)$ & (26.6\% of sample) \\
\hline
\end{tabular}




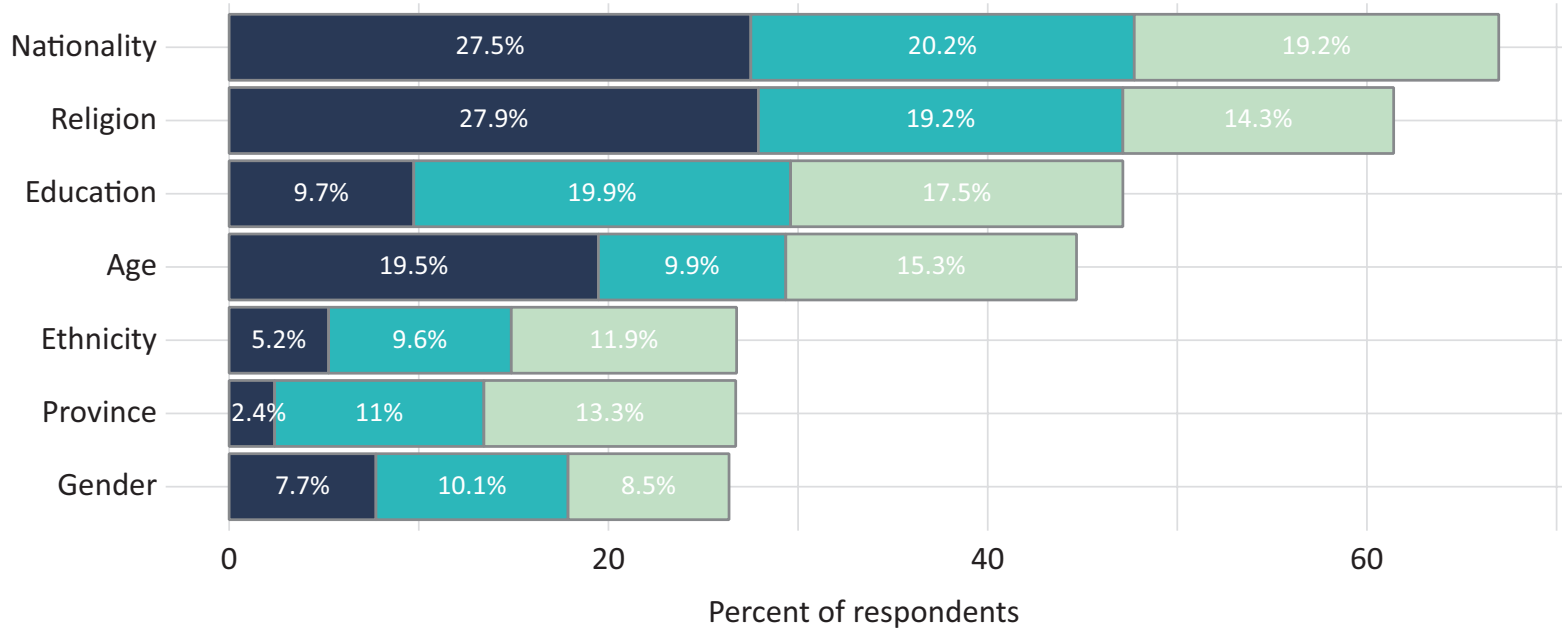

Ranked first $\square$ Ranked second $\quad \square$ Ranked third

Figure 2. Most important characteristics for group identity. Notes: Sample: Deltapoll | Indonesia | 24-28 December 2018 | $n=2,003$ | Question: Many people belong to a larger group of people because of a shared culture, history, background interests or identity. Thinking about the group(s) of people you identify most strongly with, please indicate the first, second and third most important characteristics that matter to your group identity.

we asked respondents to consider the following dimensions of identity: gender, age, religion, ethnicity, religiosity, but also their personality type and attitude towards traditions. The options offered to respondents are shown in Table 2.

While there is no single prototypical leader among respondents, several patterns emerged in respect to our key criteria:

As for gender: A whopping $86 \%$ chose a male leader and only $14 \%$ chose a female leader. While women were more likely to choose a female leader than male respondents, they still only chose a female leader $18 \%$ of the time compared to only $10 \%$ of men. Respondents from North Sumatra are most likely to prefer women leaders (23\%) and those from West Java were the least (9\%).

As for age: Given the choice of a 27, 37, 47, 57, or 67 -year old leader, $46 \%$ of respondents preferred a 47-year old.

As for religious faith: $79 \%$ of respondents preferred a Muslim leader. As expected, this was mostly driven by respondents selecting their own faith, with $94 \%$ of Muslims selecting a Muslim leader, 63\% of Protestant Christians selecting a Protestant Christian leader and 62\% of Catholic Christians selecting a Catholic Christian leader. Notably, while respondents of more minority religions did still favour their own, they were more likely to nominate a Muslim leader. For example, although $47 \%$ of Hindus favoured a Hindhu leader, $40 \%$ chose a Muslim leader.

As for ethnicity: $60 \%$ of respondents choose a leader with the same ethnicity as them. Men were more likely to do so $(64 \%)$ than women (57\%). East Javanese (74\%) respondents were most likely to choose a leader with the same ethnicity as them and South Sulawesi respondents were the least likely to do so ( $40 \%$ of the time).
As for religiosity: In terms of the importance of a leader's faith, 52\% wanted a leader who had a very strong faith and made religion central to their life and work and another $37 \%$ wanted a leader who regularly attended their place of worship. There were no significant differences between men and women. West Java (58\%) were more likely to choose a leader who have a very strong faith and make religion central to their life, and respondents from South Sulawesi were least likely (39\%).

As for tradition: A majority (59\%) chose a leader who would protect existing traditions to keep things how they are. There were no significant differences between men and women respondents, or across the provinces.

As for personality: When given the choice between a leader who was either (1) honest and fair; (2) humble and forgiving; (3) able to inspire people to follow them; (4) confident and outspoken; or (5) able to get things done, $66 \%$ of respondents want a leader to be honest and fair. There were no significant differences between men and women. Jakarta Special Capital Region (19\%) were more likely to choose a leader who could get things done than respondents from North Sumatra (9\%).

In sum, we note three clear trends from the data. First, respondents tend to 'design' leaders that embody their own personal characteristics and those of their group. Second, this effect is strongest in terms of religious faith, but weakest in terms of gender-where large majorities among both women and men prefer male leaders. Here, shared perceptions of prototypicality at the group level clearly outweigh any sense of shared female identity. This also confirms the last placed position of gender in Figure 2. Third, and finally, where respondents are in a minority group, they are less likely to select their own 'type' and defer to majority characteristics. This was illustrated by 4 in 10 Hindu respondents 
nominating a Muslim leader as best placed to represent the wider interests of the group that they identify with. Together, these results, descriptively, confirm the presence of prototypicality in leader selection in Indonesia. But what effect does prototypicality have on citizens' perceptions of leaders and their support. This is what we turn to next.

\subsection{Research Question 2}

Having been allocated to read the manifesto statement from either a prototypical or non-prototypical leader, as explained above, we measured people's trust, perception of effectiveness, and belief that the leader would protect the interests of the respondent's group. Figure 3 shows the difference in responses between the two groups.

The results demonstrate a clear effect of prototypicality. Prototypical leaders are more trusted, scoring an average rating of 7.6 as opposed to 5.5 (a $39 \%$ increase). Prototypical leaders are considered more capable or effective, scoring an average rating of 7.6 versus 5.6 for the non-prototypical leader (a 35\% increase). And prototypical leaders are felt more likely to protect the interests of the group, scoring an average rating of 7.5 versus 5.3 for the non-prototypical leader (38\% increase). Taken together, this suggests that, along these key indicators of support, prototypical leaders are getting a boost of roughly a third over and above their non-prototypical rivals.

The marginally stronger effect for trust (and interests) is supported by previous studies that suggest prototypicality is more closely linked to trust than effectiveness (Van Lange, 2015). They confirm the in-built relationship between prototypicality and trust that lies at the core of social identity theory; these leaders are trusted because their identity is more closely tied to the identity of the group, and trusting them is akin to trusting the group identity (Van Lange, 2015).

\subsubsection{Research Question 3}

Finally, we wanted to see whether prototypicality effects would still hold when respondents were updated on the actual performance of leaders. Specifically, would success or failure outweigh identity? Figure 4 shows the difference in responses on our three indicators of interest across the four groups, as described in the data and methods section: prototypical successful leaders, prototypical failed leaders, non-prototypical successful leaders, non-prototypical failed leaders.

A consistent story and hierarchy emerge. First, successful leaders are consistently perceived as more trusted, capable, and likely to represent people's interests than unsuccessful leaders. Second, prototypical leaders are consistently perceived as more trusted, capable, and likely to represent people's interests than nonprototypical leaders. But third, even when successful non-prototypical leaders are still perceived as less trusted and likely to represent people's interests than unsuccessful prototypical leaders. Only perceptions of capability are statistically indistinguishable between successful non-prototypical leaders and failed prototypical leaders. In sum, identity overrides reported success or failure in the evaluation of leadership: Failure is punished more harshly when leaders are non-prototypical. Success cannot, in other words, consistently match the effects of prototypicality on positive evaluations of leadership. In short, there is an in-built protection for prototypical leaders. Their identity provides a buffer against failure. On the other hand, non-prototypical leaders seem to face a glass ceiling in terms of how far their

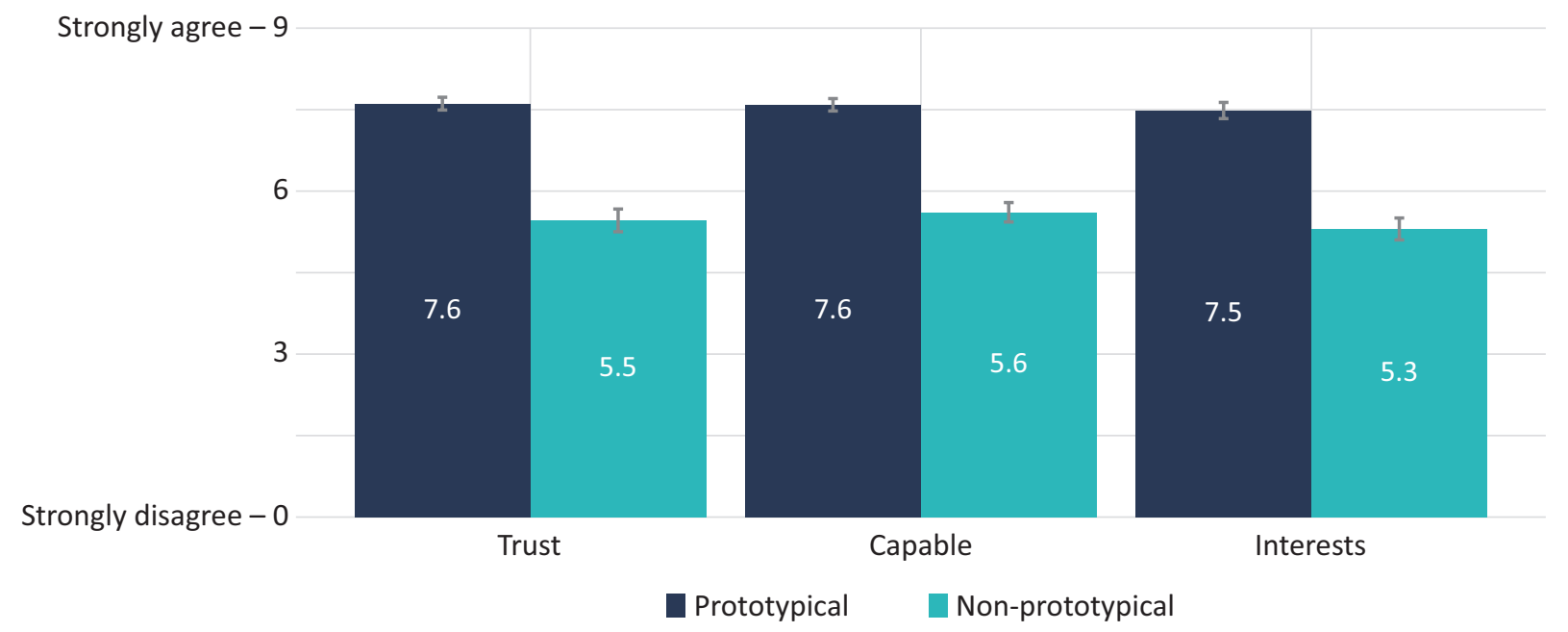

Figure 3. The effects of prototypicality on trust, capability, and interests. Notes: Sample: Deltapoll | Indonesia | 24-28 December 2018 | Sample size $n=2,097$ | Data weighted to be representative at the Province | Question: I could absolutely trust this person as a Bupati/Walikota | This person would be a very capable leader as a Bupati/Walikota | This leader would represent my group's interests as a Bupati/Walikota. 


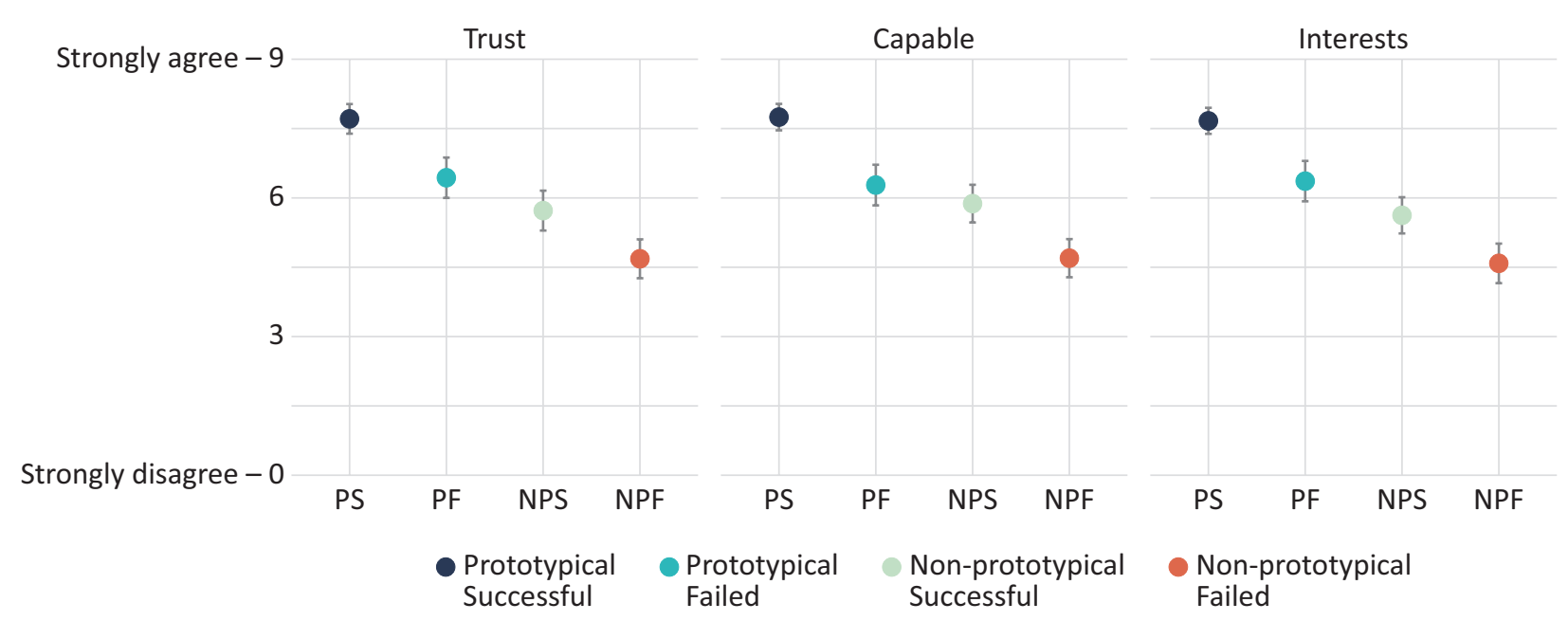

Figure 4. The effects of leader success and failure. Notes: Sample: Deltapoll | Indonesia | 24-28 December 2018 | Sample size $n=2,003$ | Data weighted to be representative at the Province | Question: I could absolutely trust this person as a Bupati/Walikota | This person would be a very capable leader as a Bupati/Walikota | This leader would represent my group's interests as a Bupati/Walikota.

success can build perceptions of their trustworthiness and capability.

We looked to see if there are any statistically significant and substantively interesting differences in how different groups in our sample responded to the second experimental treatment. Notably, women responded differently to men to the extra information about success and failure. Female respondents were more likely to punish prototypical failure and more likely to react positively non-prototypical success compared to men-in other words, woman weighed the importance of the new information about success and failure more strongly against the identity of the leader, meaning the identity effects of prototypicality were smaller for women. In terms of age, the 40-59 age group appear unique in upgrading both non-prototypical success and prototypical success-so it's not that they adjusted their view of the importance of identity, per se, but that they rewarded successful leaders regardless of it. University degree holders upgraded prototypical successful leaders too, but were not different to non-degree holders in relation to the other three treatments. Finally, in terms of religiosity, respondents who make faith central to their lives were unique in rewarding prototypical success more than those at other levels of religiosity, and punished successful but non-prototypical leaders in terms of trust and capability, but not interest.

\section{Discussion}

Our findings suggest that identity trumps performance and that ethnic identity matters less than religious identity and attitudes around tradition and conservatism in Indonesia. We use this final section to reflect upon these findings within the Indonesian context and flag up other observational studies that support the experimental findings presented here. We acknowledge there may be a gap between reported perceptions of leadership in a survey experiment and actual voting behaviour. By triangulating with previous studies of voting behaviour in local elections in Indonesia we reflect on robustness of our results. These studies illustrate the dynamic trends of Indonesian voters' support and assessment of the candidates. Plus, we use these discussion to underline the fact that the dimensions of prototypicality vary over space and time and are always contingent.

Prasetyawan (2014) examines the two local elections in Jakarta (2007 and 2012) and emphasises how the dynamic relations between ethnicity and voting patterns needs to be understood within the relevant political context. The relations between ethnicity and voting changed in magnitude between the two election cycles, due to a shifting political context and pressing issues that Jakartans were confronted with, i.e., flood. Prasetyawan (2014) argues that while ethnicity remains important notably, in the 2007 election, the capabilities of leaders gained more importance than ethnicity in the 2012 election. This trend continued into the 2017 Jakarta election as people's voting behaviour suggested performance, programmatic politics, ideology and religion could trump ethnic considerations (Aspinall, 2017). The significant relations between identity and support for political leadership in Jakarta local elections appear to have shifted over the period.

In 2007 Jakarta experienced its first direct local election. Here ethnic identity was predominant. Jakarta had never had a native Betawi Governor. The 2007 election was won by Fauzi Bowo, a long-term bureaucrat and a Betawi. His competitor was Adang Dorojatun, a party elite, a retired police general, of Sunda ethnicity. During the campaign, both candidates played the ethnic identity card to secure votes. However, in 2012, this changed with a non-native Jakartan winning. In the 2012 election, Joko Widodo was elected Governor with his Deputy 
Basuki Tjahaya Purnama or more popularly known as Ahok. Widodo is Javanese and was mayor of Solo. Ahok is a Christian, Chinese, and was Bupati of East Belitung in 2005, and then won a seat in the national parliament from a district in Bangka Belitung Province in 2009. Together they won $53 \%$ votes against the incumbenta native Jakartan, alongside his deputy, a fellow native Jakartan, and retired military general. The outcome of the 2012 local election in Jakarta illustrates the dynamic and fluid nature of identity for Jakartans at the time (Hatherell \& Welsh, 2017). Therefore, the salience of identity, and which dimensions, should always be understood in context-and ethnicity is often not always the main determining factor.

Ahok confirmed his candidacy in 2016 for the following year's election. Despite his reputation for controversial policies and leadership style, support for Ahok had been consistently strong and commentators believed he could win in the first round of election (Aspinall, 2017). However, during the campaign period, Ahok was charged with blasphemy and put on trial through to 2017, meaning that the election was between three pairs of candidates, one of whom was in court. Meanwhile, conservative Muslim groups arranged a series of demonstrations, massive prayer meetings, and rallies to condemn Ahok and demand heavy legal sanctions. Yet the results of the first round of the election saw Ahok winning $43 \%$ of the vote, while his contender Anies Baswedan only got $40 \%$.

If the blasphemy case was beneficial for the other candidates, it was not enough to outvote Ahok in the first round. But, the court's decision of two year's jail sentence for Ahok has been referred to as a historical turning point for politics in Indonesia, of rising religious intolerance and the ascendance of hardline conservative Islam (Bourchier, 2019; Hefner, 2019). Equally, though, others have argued that the 2017 Jakarta election should not be understood simply as failed pluralism and religious tolerance. Despite the large campaign condemning Ahok as a menace to Islam and the fact that he lost in the second round of 2017 election, there is still a significant proportion of Jakartan voters who favor programmatic politics, amid the rising of organized conservative Islamist groups that press forward with identity mobilization.

Another study, of the 2010 local election in Medan city, North Sumatra, conducted by Aspinall, Dettman and Warburton (2011), suggests that while identity can be utilized by candidates to mobilize votes, the question of which identity is more politically salient is contingent on other factors such as voters' access to resources. The multiple candidates in the first round of the election were from the majority religion, although they came from various ethnic groups. At this first stage, the crosscommunity background of candidates was used to attract votes. When there were two candidates left in the second round, however, the focus was switched to religious identity which was used to mobilize votes from various ethnic groups to beat a minority candidate in order to preserve their access to resources. Again, a pattern reflected in our survey data. The case shows how the political salience of identity is constructed, and can shift through electoral campaigns. Another study by Fossati, Simandjuntak, and Fionna (2016) offers an analysis on data from surveys conducted in the city of Medan in North Sumatera, Samarinda in East Kalimantan and Surabaya in East Java, immediately after the local direct elections in 2015. Indications from the survey data suggest that ethnic considerations play a marginal role in the behaviour of voters, even if the report admits that it did not specifically discuss ethnic politics. Xue (2018) cites a report of voters' behaviour conducted by Ananta, Arifin, \& Suryadinata (2004), which shows that ethnicity is a less important factor in the direct election of local leaders in South Sulawesi and Bangka Belitung, compared to West Kalimantan where ethnic consideration is more important to the voters. Interestingly, South Sulawesi emerges from our survey data as something of an outlier context too. We believe that taken together these findings suggest that despite the significance of ethnicity, other intervening factors such as pressing political issues at the local level may mediate the effect of ethnic identity mobilization.

\section{Conclusion and Implications}

This study offers new empirical evidence that supports the social identity theory of leadership, but in contrast to the bulk of previous studies, shows this effect in a non-Western setting, in the political domain. The overall finding from this research is that identity matters for people's willingness to support leaders. There is a significant effect of identity on perceptions of how effective leaders are in Indonesia. These leaders have a built-in reservoir of trust based on their identity, that can buffer them against repercussions from ineffectiveness. This analysis shows that citizens assess their leaders based on their identity primarily and their performance secondarily. It may well be true that persistent poor performance and neglect will eventually overwhelm prototypicality-but in recent years we have seen a good many political leaders test this, seemingly to beyond breaking point.

Our results presented here, though, have added some detail to the more general thesis. First, at least in the current Indonesian context, religious identity trumps ethnicity. Secondly, while many citizens will say that gender is not a key category, our exercise in inviting respondents to build their own prototypical leader overwhelmingly revealed that it is typically a male leader that is preferred. Thirdly, we showed that prototypicality primarily boosts people's trust. But fourthly, that the effects of prototypicality are not evenly manifestedmost importantly women appear to be less encouraging of prototypical failure and less dismissive of nonprototypical success than men are, and that in certain contexts (here, South Sulawesi) prototypical leaders are viewed more skeptically.

It is important to stress, however, that the nuances of these findings illustrate that the prototypicality effect is 
not generalisable across Indonesia or beyond, because leadership evaluation is always situational. Leaders are evaluated in a proximate context of their organisation or sector, as well as in the distal context of a particular cultural and political system (Aviolo, 2007). While the overall results are consistent and clear, it is possible to identify outlier cases where prototypicality does not trump effectiveness-future work can and should seek to test the relative importance of different dimensions of identity, for example through focus groups and or leveraging conjoint experimental techniques. The findings here would also be strengthened by testing for clientelism and patronage, testing for a more diverse set of leadership behaviours or outcomes than simply success or failure, by using field or natural experiments to test real world voting or electoral behaviour (not just survey outcomes).

From a development perspective, this study suggests there is further value in testing the prototypicality effect across diverse settings. The pattern across much of the world-developed and developing-is that leaders are often not responsive to followers' interests, and do not work towards inclusive development, nor deliver on election promises. These leaders are, however, not always unpopular. Prototypical leaders may have considerably more room for manoeuvre in the sense that they can fail but still be perceived as trustworthy. On the other hand, non-prototypical leaders may have to work harder to gain trust through effective performance or appealing to sub-groups in the population that are more likely to weigh effectiveness against identity. Finally, for those wishing to support leadership, whether domestically or from the outside, the results underline the importance of thinking politically about the significance of identity, not just thinking technically about effective leadership. Leadership development training and support can help leaders think about how they present or narrate their connection with their followers-without this, effective leadership may not be enough.

\section{Acknowledgments}

We would like to thank participants at presentations of earlier versions of the article at the '2019 RDI Conference: Leadership for Inclusive Development,' in June 2019; '2019 Effective States and Inclusive Development Research Centre 2019 Conference: From Politics to Power? Rethinking the Politics of Development,' University of Manchester, in September 2019; and an internal seminar presentation to the Australian Department of Foreign Affairs and Trade. We would also like to thank Dirga Ardiansa, Simon De Lay, and Chris Roche and two anonymous reviewers for their excellent comments on and helping to improve the article. We also acknowledge the financial support of the Developmental Leadership Program (DLP), the Indonesian Knowledge Sector Initiative (KSI), and the Australian Department of Foreign Affairs and Trade.

\section{Conflict of Interests}

The authors declare no conflict of interests.

\section{References}

Aaldering, L., \& Vliegenthart, R. (2016). Political leaders and the media. Can we measure political leadership images in newspapers using computer-assisted content analysis? Quality \& Quantity, 50(5), 1871-1905.

Abrams, D., de Moura, G. R., Marques, J. M., \& Hutchison, P. (2008). Innovation credit: When can leaders oppose their group's norms? Journal of Personality and Social Psychology, 95(3), 662-678.

Ananta, A., Arifin, E. N., \& Suryadinata, L. (2004). Indonesian electoral behaviour: A statistical perspective. Singapore: Institute of Southeast Asian Studies.

Andrews, M. (2016). Going beyond heroic leaders in development. Public Administration and development, 36(3), 171-184.

Aspinall, E. (2017, February 16). Interpreting the Jakarta election. New Mandala. Retrieved from https://www.newmandala.org/interpreting-jakartaelection

Aspinall, E., Dettman, S. \& Warburton, E. (2011). When religion trumps ethnicity: A regional election case study from Indonesia. South East Asia Research, 19(1), 27-58.

Aspinall, E., \& Mas'udi, W. (2017). The 2017 pilkada (local elections) in Indonesia: Clientelism, programmatic politics and social networks. Contemporary Southeast Asia, 39(3), 417-426.

Aviolo, B. (2007). Promoting more integrative strategies for leadership theory-building. American Psychologist 62(1), 25-33.

Baretto, N. B., \& Hogg, M. A. (2017). Evaluation of and support for group prototypical leaders: A metanalysis of twenty years of empirical research. Social Influence, 12(1), 41-55.

Bawaslu. (2019). Indeks Kerawanan Pemilu Pemilihan Kepala Daerah 2018 [Election Vulnerability Index for Regional Head Election 2018]. Jakarta: Bawaslu. Retrieved from https://bawaslu.go.id/sites/ default/files/publikasi/Layout\%20IKP_BAWASLU_ 30NOV17.pdf

Bourchier, D. M. (2019). Two decades of ideological contestation in Indonesia: From democratic cosmopolitanism to religious nationalism. Journal of Contemporary Asia, 49(5), 713-733.

Bunte, M., \& Ufen, A. (2009). The New Order and its legacy: Reflections on democratization in Indonesia. In A. Ufen \& M. Bunte (Eds.), Democratization in postSuharto Indonesia (pp. 3-29). London and New York, NY: Routledge.

Chemers, M. (2002). An integrative theory of leadership. Mahwah, N.J: Psychology Press.

Corbett, J. (2019). Where do leaders come from? A leader-centred approach. Birmingham: Developmen- 
tal Leadership Program.

Davidson, J. (2018). Indonesia: Twenty years of democracy. Cambridge: Cambridge University Press.

Fealy, G. (2013). Indonesian politics in 2012: Graft, intolerance and hope of change in the late Yudhoyono period. Southeast Asian Affairs, 101, 103-120.

Fossati, D., Simandjuntak, D., \& Fionna, A. (2016) A preliminary assessment of Indonesia's simultaneous direct elections (Pilkada Serentak). Perspective, 2016(1), 1-10.

Giessner, S. R., van Knippenberg, D., \& Sleebos, E. (2009). License to fail? Leader prototypicality, leader performance, and leadership endorsement. Leadership Quarterly, 20(3), 434-451.

Hatherell, M., \& Welsh, A. (2017). Rebel with a cause: Ahok and charismatic leadership in Indonesia. Asian Studies Review, 41(2), 174-190.

Hefner, R. W. (2019). Whatever happened to civil Islam? Islam and democratisation in Indonesia, 20 years on. Asian Studies Review, 43(3), 375-396.

Hogg, M. A., Fielding, K. S., Johnson, D., Masser, B., Russell, E., \& Svensson, A. (2006). Demographic category membership and leadership in small groups: A social identity analysis. Leadership Quarterly, 17(4), 335-350.

Hogg, M. A., \& Knippenberg, D. v. (2003). Social identity and leadership processes in groups. In M. P. Zanna (Ed.), Advances in experimental social psychology (Vol. 35, pp. 1-52): Cambridge, MA: Academic Press.

Hogg, M. A., van Knippenberg, D., \& Rast III, D. E. (2012). The social identity theory of leadership: Theoretical origins, research findings, and conceptual developments. European Review of Social Psychology, 23(1), 258-304.

Hudson, D., \& Mcloughlin, C. (2019). How is leadership understood in different contexts? Birmingham: Developmental Leadership Program.

Hudson, D., Mcloughlin, C., Marquette, H., \& Roche, C. (2018). Inside the black box of political will: 10 years of findings from the Developmental Leadership Program. Birmingham: Developmental Leader- ship Program.

Marques, J. M., \& Paez, D. (1994). The 'Black Sheep Effect': Social categorization, rejection of ingroup deviates, and perception of group variability. European Review of Social Psychology, 5(1), 37-68.

Menchik, J. (2019). Moderate Muslims and democratic breakdown in Indonesia. Asian Studies Review, 43(3), 415-433.

Mietzner, M. (2014). How Jokowi won and democracy survived. Journal of Democracy, 25(4), 111-125.

Mietzner, M. (2020). Authoritarian innovations in Indonesia: Electoral narrowing, identity politics and executive illiberalism. Democratization, 27(6), 1021-1036.

Power, T. (2018). Jokowi's authoritarian turn and Indonesia's democratic decline. Bulletin of Indonesian Economic Studies, 54(3), 307-338.

Prasetyawan, W. (2014). Ethnicity and voting patterns in the 2007 and 2012 gubernatorial elections in Jakarta. Journal of Current Southeast Asian Affairs, 33(1), 29-54.

Rast, D. E., Gaffney, A. M., Hogg, M. A., \& Crisp, R. J. (2012). Leadership under uncertainty: When leaders who are non-prototypical group members can gain support. Journal of Experimental Social Psychology, 48(3), 646-653.

Reicher, S. D., Haslam, S. A., \& Platow, M. J. (2018). Shared social identity in leadership. Current Opinion in Psychology, 23, 129-133.

Ullrich, J. v. D. R., \& Christ, O. (2009). Substitutes for procedural fairness: Prototypical leaders are endorsed whether they are fair or not. Journal of Applied Psychology, 94(1), 235-244.

Van Knippenberg, D. (2011). Embodying who we are: Leader group prototypicality and leadership effectiveness. Leadership Quarterly, 22(6), 1078-1091.

Van Lange, P. A. (2015). Generalized trust: Four lessons from genetics and culture. Current Directions in Psychological Science, 24(1), 71-76.

Xue, S. (2018). Ethnic mobilization in 2015 local elections in North Sumatra, Indonesia. Asian Ethnicity, 19(4), 509-527.

\section{About the Authors}

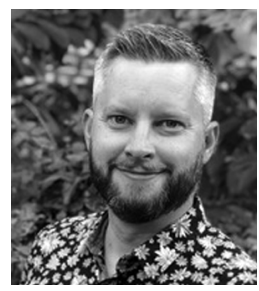

David Hudson is the Professor of Politics and Development in the International Development Department at the University of Birmingham. David's work focuses on the politics of development, in particular on the role of coalitions, leadership and power in reform processes and how development actors can think and work politically as part of the Developmental Leadership Program, migration and migration-decision making, and how people in rich countries engage with global development issues as part of the Development Engagement Lab.

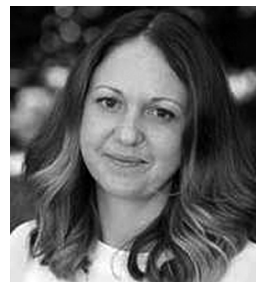

Claire Mcloughlin is Lecturer in Political Sociology in the International Development Department at the University of Birmingham. Claire's research focuses on the political sociology of vital public service delivery in conflict-affected and divided societies. In particular, she is interested in the politics of distributive justice and procedural fairness in service delivery, and the historical processes that embed welfare provision in social contracts. Claire currently conducts research on the politics of development and leadership for the Developmental Leadership Program (DLP), for which she acts as Deputy Director (Research). 


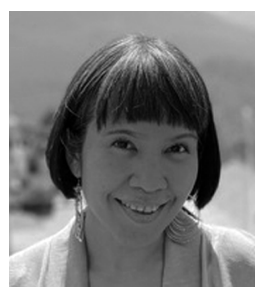

Anna Margret is an Assistant Professor at the Department of Political Science, Faculty of Politics and Social Sciences, University of Indonesia. She is also the Chair of Cakra Wikara Indonesia (CWI), a policy research institute based in Jakarta. Her work and publication can be found particularly built around the narratives of nationalisms and citizenship, research methodology, gender and politics especially looking at the debates around the politics of representation and women's political participation in Indonesia.

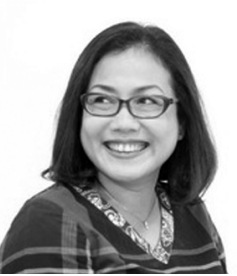

Yolanda Pandjaitan is a Lecturer at the Department of Political Science, University of Indonesia. She is also the Research Director at Cakra Wikara Indonesia, a policy research institute based in Jakarta. Her area of expertise includes Indonesian electoral system, political party system, and women's political representation in Indonesia. She writes extensively on those issues and has been involved in a number of advocacy research related to the revisions of laws on elections and political parties in Indonesia since 2001. 